\title{
Afrikaans in perspektief (Sestig jaar na amptelike erkenning)
}

Op 14 Augustus 1875 is die Genootskap van Regte Afrikaners gestig. Hulle doel was "om te staan vir ons taal, ons nasie en ons land."

Die eerste Afrikaanse taalbeweging wat hier begin het, was meer as net 'n taalbeweging. Dit was ook'n beweging vir die erkenning van die Afrikaner op kulturele, staatkundige, godsdienstige en wetenskaplike gebied.

Dié pad van Afrikaans was nie maklik nie en teen die einde van die negentiende eeu was die eerste Afrikaanse taalbeweging verby sonder dat daar enige teken van erkenning van owerheidsweë was.

Die uitbreek van die Tweede Vryheidsoorlog en die lyding wat daarmee gepaard gegaan het, het nuwe vuur in die taalstryd gebring en die tweede Afrikaanse taalbeweging het begin. Die smart van die oorlog het as voedingsbron gedien vir' $n$ nuwe gevoel van eie waarde en trots.

Die keuse tussen Afrikaans en Hollands moes nog gemaak word. Onze Jan Hofmeyr vra in 1905 "Is't ons ernst?" met Hollands. Gustav Preller pleit by sy mense "Laat't ons toch ernst wezen" met Afrikaans, en in 1908 verklaar D.F. Malan: "Het is ons ernst", erns met Afrikaans!

Op 2 Julie 1909 word die stigting van die SuidAfrikaanse Akademie vir Wetenskap en Kuns 'n werklikheid. Een van die hoofdoelstellings van die Akademie was die handhawing en die bevordering van Afrikaans.

Op 31 Mei 1910 kom die Unie van Suid-Afrika tot stand, maar Afrikaans word nog nie waardig geag om as staatstaal erken te word nie.

Langenhoven se werk moes nog kom, die Afrikaanse letterkunde moes nog sy eerste treetjies gee en taalstryders moes nog veg om hulle eie mense te oortuig dat Afrikaans hulle taal is.

Op 27 Mei 1925 word Wet no. 8 op die wetboek geplaas en daardeur word Afrikaans as volwaardige amptelike taal naas Engels erken.

'n Skrale sestig jaar gelede is Afrikaans dus eers amptelike status gegun. In 1925 was daar nog feitlik geen Afrikaanse letterkunde nie, die Bybel was nog nie vertaal nie, daar was nog geen wetenskaplike Afrikaanse handboeke of vaktydskrifte nie, 'n eie Afrikaanse vaktaal het nog nie bestaan nie en daar was nog geen gevestigde Afrikaanse akademiese tradisie nie. Selfs die Suid-Afrikaanse Akademie vir Wetenskap en Kuns het maar nog sy pad probeer vind. Arm was die taal dus. 'n Baie lang pad het voorgelê. Die agterstand by 'n wêreldtaal soos Engels was so groot dat daar talle doemprofete was wat nie wou glo dat Afrikaans kan oorleef nie.

Hoe lyk dit na sestig jaar? Hoe het die klein taaltjie gevorder langs die wêreldtale wat eeue se voorsprong gehad het?

Een argument wat dikwels gehoor word, is dat Afrikaans as publikasietaal besig is om te verdwyn. Daar word dan gewys op die feit dat natuurwetenskaplikes hoofsaaklik in Engels publiseer. Op grond hiervan word Afrikaans dan afgeskryf as minderwaardig en oor sy toekoms word groot vraagtekens geplaas. So 'n houding is nie alleen onbillik nie, maar getuig ook van 'n verbasende onkunde. Toe die eerste Blankes in Tafelbaai voet aan wal gesit het, het hulle Hollands gepraat. Afrikaans sou eers eeue daarna as taal erken word. Maar toe reeds was Engels, Frans en Spaans eeue-oue wêreldtale met 'n ou gevestigde wetenskaplike vaktaal en wetenskaplike tradisie. Moes Afrikaans in sy kort bestaan nog hierdie agterstand ook ingehaal het? Die feit dat wetenskaplikes wat internasionaal gelees wil word van 'n internasionale taal gebruik maak om hulleself verstaanbaar te maak, is mos geen verraad teenoor Afrikaans nie. Dit is ook geen rede om Afrikaans te wil afskryf nie. Afrikaanse vaktydskrifte, Afrikaanse handboeke, Afrikaanse woordelyste en 'n tydskrif soos hierdie bewys immers dat Afrikaans as publikasietaal wel hier tot sy reg kom.

As 'n mens Afrikaans in sy regte historiese perspektief plaas, kan jy nie anders as om verbaas te staan oor dit wat reeds bereik is nie. Die Afrikaanse letterkunde het fenomenaal gegroei, 'n eie Afrikaanse vaktaal het tot stand gekom, talle Afrikaanse wetenskaplike handboeke is gepubliseer, die Afrikaanse perswese, radio en televisie is gevestig, die Bybel is in Afrikaans vertaal, woordeboeke, woordelyste en ensiklopediee het verskyn. Afrikaans het die handelswêreld, die versekeringswese en die nywerheid betree, Afrikaanse skole en universiteite is gevestig.

Daar is talle probleme op baie lewensterreine vir Afrikaans. Een daarvan is reeds hierbo aangeraak. Afrikaans kom byvoorbeeld ook nie ten volle tot sy reg in die handelswêreld en die nywerheid nie. Daar is bewyse van verwaarlosing en agteruitgang. Groot navorsingsprojekte het dit al telkens onderstreep. Maar - en dit is belangrik - om net negatief in sak en as op die probleme te konsentreer en net die swart kant te wil raaksien, is kortsigtig. So 'n negatiewe benadering kan lei tot die ondergang van Afrikaans. Ons pleit vir ' $n$ positiewe en realistiese benadering. Kyk na Afrikaans in die regte perspektief en dan word dit duidelik dat daar werk is wat gedoen moet word, dat D.F. Malan se oproep: „Dit is ons erns!” weer opnuut betekenis moet kry.

Die dinamiese groeikrag van Afrikaans oor die af- 
gelope sestig jaar behoort as ' $n$ aansporing te dien om ons taal te handhaaf en verder uit te bou. Dit is ' $n$ taak wat die Afrikaanssprekende self moet aanpak.

Die Tydskrif vir Natuurwetenskap en Tegnologie is een van die bewyse van die bruikbaarheid en die lewenskrag van Afrikaans. Laat ons dit gebruik waarvoor dit bedoel is.

$\mathrm{Na}$ sestig jaar is daar nog baie werk, maar ook baie rede tot dankbaarheid.
D.J.C. Geldenhuys Hoofsekretaris

\section{Die ontwikkeling van Afrikaans as amptelike taal}

Die amptelike erkenning van Afrikaans in 1926 het tot 'n groot bloeitydperk gelei. Een rede hiervoor is seker die feit dat Afrikaans teen 1926 reeds oor 'n baie lang tydperk heen 'n algemene gebruikstaal in Suid-Afrika was. Die nie-amptelike status daarvan het nie verhoed dat Afrikaans geskryf word nie - belangrike literêre en ook vakwetenskaplike en populêre skryfwerk is lank voor 1926 al in Afrikaans gedoen. As spreektaal is Afrikaans natuurlik al 'n paar eeue oud.

'n Tweede rede vir die opbloei van Afrikaans na 1926 is egter sekerlik die status wat dit as amptelike taal naas Engels verkry het. Dis asof daar 'n groter selfwaarde en selfversekerdheid by Afrikaanse taalgebruikers na vore getree het. Op vakwetenskaplike gebied het daar 'n nuwe ywer gekom om die gebiede wat nog nie deur Afrikaans bestryk is nie, in Afrikaans toeganklik te maak. So kom daar mettertyd oor die afgelope stuk of vyftig jaar al hoe meer teksen handboeke in Afrikaans beskikbaar, en word ' $n$ groot hoeveelheid vakwetenskaplike en populêr-wetenskaplike artikels geskryf.

As ' $n$ mens ' $n$ vergelykende studie van die omvang van die Afrikaanse woordeskat in woordeboeke onderneem, kom jy sterk onder die indruk van die groei en uitbreiding daarvan. Een faset van hierdie groei raak die uitgebreide omvang van die Afrikaanse vakterminologie. Daarom dat daar ook 'n bestendige vordering op die gebied van vakwoordeboeke in Afrikaans was.

Hierdie groei op die gebied van die vakwetenskaplike woordeskat in Afrikaans moet nie los gesien word van die ontwikkeling van ons taal op die wyere terrein van die lewenservaring in die algemeen nie. Nie net die geesteswetenskappe nie, maar ook maatskaplike terreine soos die politiek, ontspanning, sport en die uitgebreide ontwikkeling van die massakommunikasiemedia (die radio, televisie, film en die pers) gee oorvloedig blyke van die algemene lewenskragtigheid van Afrikaans.

Hoewel Afrikaans wat sprekersgetalle betref 'n klein taal is, en ten spyte van die bedreigings wat op Afrikaans se pad in 'n vyandige wêreld voorkom, toon die toenemende werksaamheid op alle lewensterreine waar Afrikaans gebruik word, dikwels 'n besondere gehalte. Dit is in die nastrewing van gehalte in die taalskeppende en taalvernuwende werksaamhede dat Afrikaans hom steeds sal kan handhaaf.

L.C. Eksteen 